\title{
Correction to: Petrogenesis of basaltic dikes from the Manjo area (Western Cameroon): insights into the Paleozoic magmatism at the northern margin of the Congo craton in Cameroon
}

\author{
Noël-Aimée Keutchafo Kouamo ${ }^{1}$ - Depesquidoux Tchato Tchaptchet ${ }^{1}$ • Anne Laure Tezanou Ngueguim ${ }^{1}$. \\ Nicole Armelle Simeni Wambo ${ }^{2}$ - Jean Pierre Tchouankoue ${ }^{1}$ - Ciro Cucciniello ${ }^{3}$
}

Published online: 24 June 2019

(C) Saudi Society for Geosciences 2019

Correction to: Arabian Journal of Geosciences (2019) 12: 281 https://doi.org/10.1007/s12517-019-4424-y

The original version of this paper was published with error. The name of the third author should be "Tchaptchet" rather than "Tchatptchet". Given in this article is the corrected author name "Depesquidoux Tchato Tchaptchet".

Pulisher's note Springer Nature remains neutral with regard to jurisdictional claims in published maps and institutional affiliations

The online version of the original article can be found at https://oi.org/ 10.1007/s12517-019-4424-y

\footnotetext{
Jean Pierre Tchouankoue

tchouankoue@yahoo.com

1 Department of Earth Sciences, University of Yaoundé I,

Yaounde, Cameroon

2 Department of Earth Sciences, University of Ngaoundéré,

Ngaoundere, Cameroon

3 Dipartimento di Scienze della Terra, dell'Ambiente e delle Risorse (DiSTAR), Università di Napoli Federico II Complesso

Universitario Monte Sant'Angelo, Via Cinthia 26,

80126 Napoli, Italy
} 